Original Article

\title{
Identification of terrestrial gastropods families found in district Swat, Pakistan
}

\author{
Identificação de famílias de gastropódeos terrestres encontradas no distrito Swat, \\ Paquistão
}

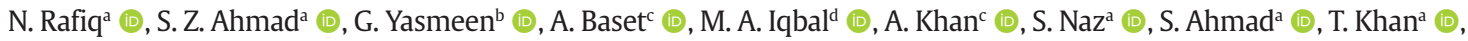 \\ M. Kamala* (D) and A. Alia (D) \\ aAbdul Wali Khan University, Department of Zoology, Mardan, Pakistan \\ bUniversity of Karachi, Department of Zoology, Karachi, Pakistan \\ 'Bacha Khan University, Department of Zoology, Charsadda, Pakistan \\ ${ }^{\mathrm{d} G o m a l ~ U n i v e r s i t y, ~ D e p a r t m e n t ~ o f ~ Z o o l o g y, ~ T a n k ~ C a m p u s, ~ D e r a ~ I s m a i l ~ K h a n, ~ P a k i s t a n ~}$
}

\begin{abstract}
Very little is known about the malacofauna in district Swat of Khyber Pakhtunkhwa province, situated in the Northern part of Pakistan. The Swat valley possesses a variety of suitable environmental conditions, providing different types of habitats for both flora and fauna. Taken into consideration these points, the present study was conducted to explore the terrestrial snails diversity in agricultural and non-agricultural fields in the lower Swat valley. A total of 417 shells were collected from three sites: Kokarai, Kanju Township, and Deolai. Based on conchological features, three families: Bradybaenidae, Hygromiidae, and Zonitidae were identified using different terrestrial snail keys. In Kokarai and Deolai, shells of members of all the above-mentioned families were found from agricultural fields. In Kanju Township, shells of members of the family Bradybaenidae and Zonitidae were found. From these findings, it was concluded that district Swat possesses a significant malacofauna which was unexplored before and aided more to the existing literature on malacofauna. It also supports the idea that the agroecosystem is rich in species diversity. Further in-depth and extensive study is recommended to be carried out for a detailed taxonomy of the described terrestrial gastropod families.
\end{abstract}

Keywords: molluscs, gastropods, Bradybaenidae, Hygromiidae, Zonitidae, shells.

\begin{abstract}
Resumo
Muito pouco se sabe sobre a malacofauna no distrito de Swat, na província de Khyber Pakhtunkhwa, situada na parte norte do Paquistão. $O$ vale do Swat possui uma variedade de condições ambientais adequadas, proporcionando diferentes tipos de habitats para a flora e a fauna. Levando em consideração esses pontos, o presente estudo foi conduzido para explorar a diversidade dos caracóis terrestres em campos agrícolas e não agrícolas no vale inferior de Swat. Um total de 417 conchas foram coletadas em três locais: Kokarai, Kanju Township e Deolai. Com base em características concológicas, três famílias: Bradybaenidae, Hygromiidae e Zonitidae foram identificadas usando diferentes chaves de caramujos terrestres. Em Kokarai e Deolai, conchas de membros de todas as famílias mencionadas acima foram encontradas em campos agrícolas. No município de Kanju, foram encontradas conchas de membros da família Bradybaenidae e Zonitidae. A partir dessas constatações, concluiu-se que o distrito de Swat possui uma malacofauna significativa que antes era inexplorada e ajudava mais a literatura existente sobre a malacofauna. Também apoia a ideia de que o agroecossistema é rico em diversidade de espécies. Recomenda-se a realização de um estudo mais aprofundado e extenso para uma taxonomia detalhada das famílias de gastrópodes terrestres descritas.
\end{abstract}

Palavras-chave: moluscos, gastrópodes, Bradybaenidae, Hygromiidae, Zonitidae, conchas.

\section{Introduction}

Phylum Mollusca is the second largest taxon of the animal kingdom after Arthropods (Abbott, 1989; Chapman, 2009). They are found in both aquatic and terrestrial habitats (Miller and Harley, 2001). Economically, they are very important that is ranging from eating table such as Helix pomatia (escargot) that is used as a food in many countries worldwide like France and China to their role as an intermediate host in the transmission of parasites such as genus Schistosoma (Trematods), causing Schistosomiasis (Miller and Harley, 2001). Despite their importance, these

*e-mail: mustafakamaluok@gmail.com

Received: February 5, 2021 - Accepted: March 16, 2021

This is an Open Access article distributed under the terms of the Creative Commons Attribution License, which permits unrestricted use, distribution, and reproduction in any medium, provided the original work is properly cited. 
macro-invertebrates still haven't got much more attention from biologists throughout the world including Pakistan (Pokryszko et al., 2009).

Among the molluscs the class Gastropoda is the vast group having about 35,000 living species in both aquatic and terrestrial habitats (Miller and Harley, 2001). A few studies were carried out in different regions of Pakistan regarding gastropods diversity such as the diversity of land snail was studied in different croplands like sugarcane, wheat, fodder vegetable field and ditches in Faisalabad district (Punjab), Pakistan. The study concluded that the croplands possess a high diversity as compared to ditches because of the polluted environment in ditches (Altaf et al., 2016). Many snail species such as Zootecus agrensis, $Z$. chion, Z. polygyratus, Z. gracilor minor and Z. pullus were reported from five sites of Baluchistan and Sindh, Pakistan (Girod and Balzarini, 2017). Based on over 3500 collected shells from different sites of Pakistan, 22 species were reported including 12 new species belonging to the superfamily Pupilloidea that indicated that the Northern part of Pakistan is very diverse for Pupilloidea species (Pokryszko et al., 2009). Three shell-less snail/slug species: Anadenus altivagus, Theobald, 1862, Deroceras laeve, O.F. Muller, 1774, and Candaharia rutellum, Hutton, 1849 were also reported from the Northern area of Pakistan (Wiktor and Auffenberg, 2002).

Swat valley is situated in the Northern part of Pakistan $\left(35^{\circ} 22.60^{\prime} \mathrm{N}, 72^{\circ} 10.60^{\prime} \mathrm{E}\right)$ and possesses an unusual climatic condition with rich flora and fauna (Ahmad et al., 2015). Based on the previous studies it can be hypothesized that Swat valley must possess a significant malacofaunal diversity. The present study was aimed to examine the diversity of terrestrial snails in Swat valley. The present study mainly focused on the taxonomic account of the families.

\section{Materials and Methods}

\subsection{Study area}

The study was conducted in the lower Swat valley, situated in the Northern part of Pakistan in Khyber Pakhtunkhwa province (Figure 1 ). The coordinates are $35.2227^{\circ} \mathrm{N}, 72.4258^{\circ} \mathrm{E}$. It shows a significant variation in altitudes ranging from $600 \mathrm{~m}$ to 6000 m.a.s.l. and consists of plain areas like Chakdara, Batkhela, Barikot Tehsils to a high peak like sub-alpine and alpine regions (2300m - 6000 m.a.s.l.). From these high peaks river Swat is the only drainage basin (Ahmad et al., 2015).

The meteorological study shows the fluctuation in the average temperature annually, such as in June temperature goes up to $32.71^{\circ} \mathrm{C}$ while fall to $1.32^{\circ} \mathrm{C}$ in January. The range of precipitation from high to lowest value is $143.0 \mathrm{~mm}$ in July and $20 \mathrm{~mm}$ in November and December. The relative humidity is $82.58 \%$ in August and 54.41\% in May (Ahmad et al., 2015).

The valley also possesses a rich flora including artificial and natural forests, cropland forests such as low-altitudinal forests occur in the range of $600 \mathrm{~m}$ to 1600 m.a.s.l. and monocrop forests occur between the range of $1900 \mathrm{~m}$ to 2700 m.a.s.l. (Ahmad et al., 2015). Surprisingly, a rich

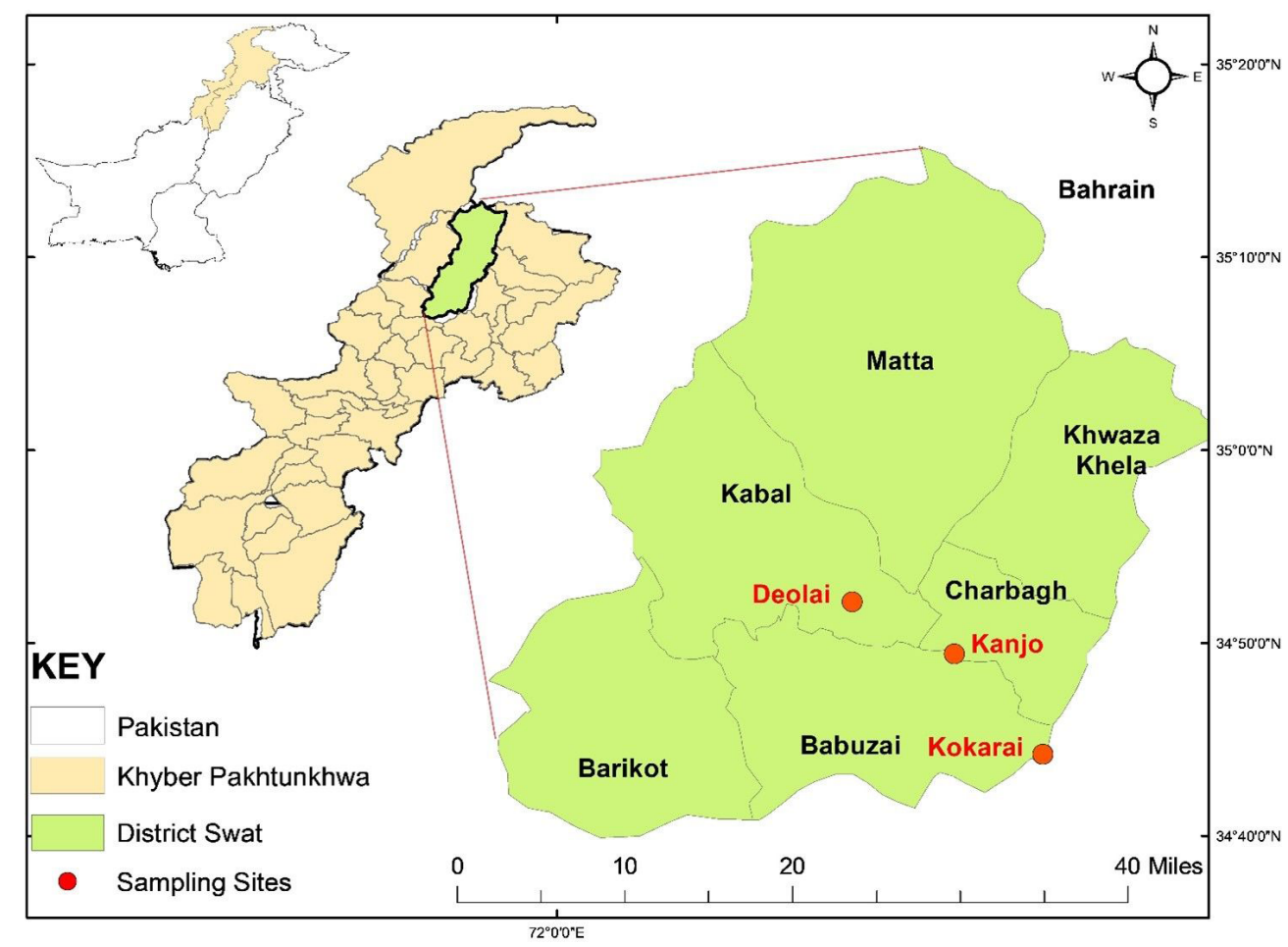

Figure 1. Map of district Swat showing sampling sites i.e. Kokarai, Kanju township and Deolai. 
fauna of different types of residents, as well as migratory birds are found here. Not only the avian fauna but also many types of mammals and reptiles are examined in this valley (Ahmad et al., 2015).

\subsection{Collection and preservation}

The collection and preservation of samples (dry shells) were performed according to the protocols provided by "Tom Ridge Environmental Centre (2016)" at Presque Isle, entitled "Guidelines and Procedures for the Malacology Collection of the Tom Ridge Environmental Center at Presque Isle Gastropoda - snails, Bivalvia - mussels" ("Integrated Taxonomic Information system,") with some modifications. The collection period was from April 2019 to June 2019. Samples were collected from three sites; Kanju township (898 m.a.s.l.), Deolai (918 m.a.s.l.) and Kokarai (990 m.a.s.l.) of lower Swat only (Figure 1). Samples were collected by hand from different habitats such as agricultural lands, mosses, shaded ravines, from the bank of streams and river swat.

Preservation was done after cleaning the specimens (shells) with detergent in warm water. To protect the shells from damage, gypsum was used to fill the shells, treated with the antiseptic agent for sterilization and then polished with varnish (wood polish) for surface protection.

\subsection{Identification}

Different conchological features like shell texture (sculpture), height, width, number of whorls, shape of aperture, coiling of shell i.e. clockwise (dextral) or anticlockwise (sinistral), presence or absence of columella, operculum, and types of umbilicus were examined for identification of terrestrial snails (Gastropods) to the family level through online identification tools and keys provided by the guide entitled as "Field guide to the non-marine molluscs of Southeastern Australia" (Smith and Kershaw,
1979). The measurable features (such as shell height, width, etc.) were measured through Vernier caliper.

\section{Results}

A total of 417 shells were collected from three sites: Kokarai, Deolai and Kanju Township (Table 1). Three families were identified namely, family Bradybaenidae, family Hygromiidae, and family Zonitidae. Shells characteristics of the family Bradybaenidae, family Hygromiidae, and family Zonitidae are given in Table 2.

\subsection{Family Bradybaenidae Pilsbry, 1934 (1898) (Figure 2)}

Description: Total 417 shells were collected in the study; 387 shells were identified as family Bradybaenidae shells. 211 shells were collected from Kokarai, 173 from Kanju Township, and only 3 shells from Deolai making a total of 387 shells (Table 1). The shell is sub-globose in shape and dextral (right-handed coiling) with opaque and yellow-tan periostracum and consists of 6 whorls (Figure 2A). Each whorl bears a single chest-nut color stripe just above the suture (Figure 2A). The measurable features like width (diameter) and height (length) were calculated which are equal to $26.03 \mathrm{~mm}$ (Figure $2 \mathrm{E}$ ) and $15.37 \mathrm{~mm}$ (Figure 2D), respectively. The shape of the aperture is lunate (Figure 2B). The umbilicus is narrow and partially closed by the apertural lip also called rimate (Figure 2C).

\subsection{Family Zonitidae Morch, 1864 (Figure 3)}

Description: Thirteen shells out of the total 417 were identified as family Zonitidae shells. 11 shells were collected from Kokarai, 01 shell from Kanju Township and 01 shell from Deolai (Table 1). The shell shape is sub-globose and transparent, horny-color periostracum and consists of 6 whorls (Figure 3A). The width (diameter) and height

Table 1. Number of shells of individual family collected from three sites.

\begin{tabular}{ccccc}
\hline Family & Kokarai & Kanju Township & Deolai & Total \\
\hline Bradybaenidae & 211 & 173 & 03 & 387 \\
Hygromiidae & 08 & 00 & 09 & 17 \\
Zonitidae & 11 & 01 & 01 & 13 \\
\hline
\end{tabular}

Table 2. Shells characteristics of the family Bradybaenidae, family Hygromiidae, and family Zonitidae.

\begin{tabular}{|c|c|c|c|c|c|c|c|c|c|c|}
\hline 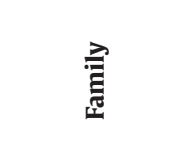 & 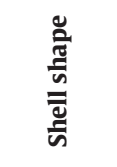 & 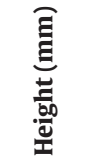 & 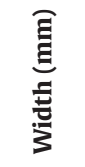 & $\begin{array}{l}\bar{\vdots} \\
3 \\
\vdots \\
\vdots \\
\vdots \\
\vdots\end{array}$ & 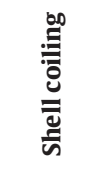 & 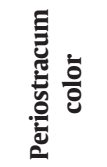 & 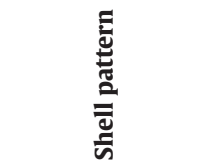 & 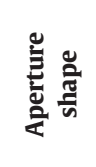 & 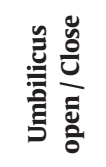 & $\sum_{\substack{\pi\\
}}^{3}$ \\
\hline Bradybaenidae & $\begin{array}{l}\text { Sub- } \\
\text { globose }\end{array}$ & 15.37 & 26.03 & 6 & Dextral & $\begin{array}{l}\text { Yellow- } \\
\text { tan }\end{array}$ & $\begin{array}{l}\text { Single stripe } \\
\text { (whorls) }\end{array}$ & Lunate & Narrow & 0.59 \\
\hline Hygromiidae & Globose & 9.75 & 12.02 & 5 & Dextral & White & $\begin{array}{l}\text { Small transverse } \\
\text { lines with spots }\end{array}$ & Lunate & Open & 0.81 \\
\hline Zonitidae & $\begin{array}{l}\text { Sub- } \\
\text { globose }\end{array}$ & 9 & 16.67 & 6 & Dextral & Horny & Absent & Lunate & Narrow & 0.53 \\
\hline
\end{tabular}




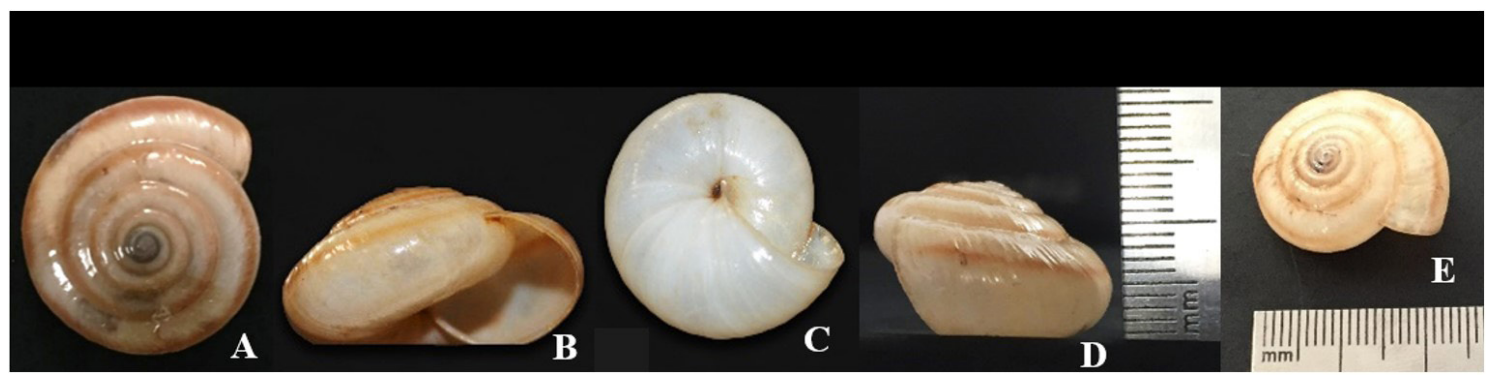

Figure 2. Family Bradybaenidae Shell: (A) Periostracum, (B) Aperture, (C) Umbilicus, (D) Height of shell, (E) Width of shell.

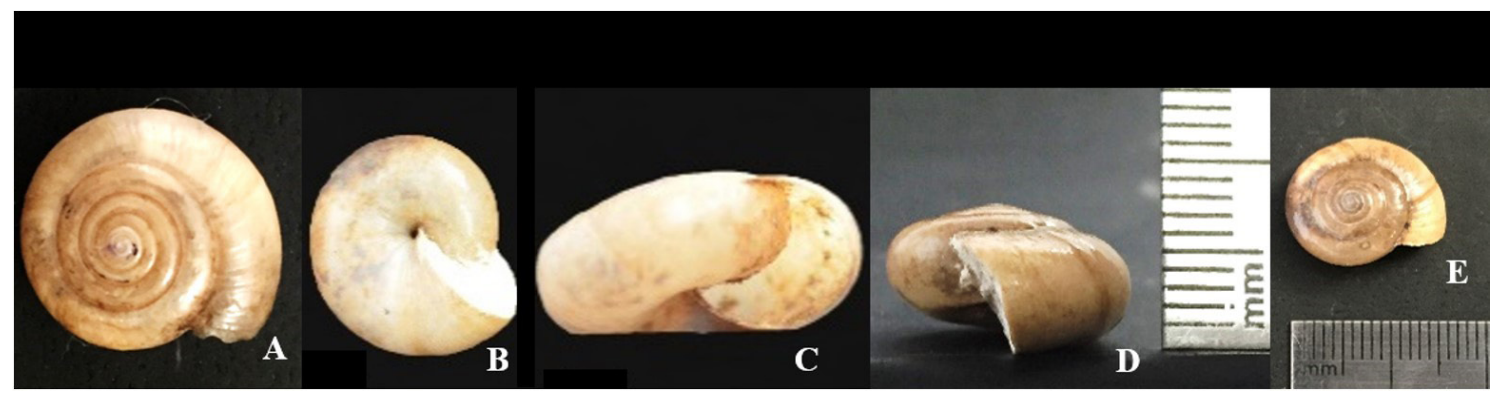

Figure 3. Family Zonitidae Shell: (A) Periostracum, (B) Umbilicus, (C) Aperture, (D) Height of shell, (E) Width of shell.

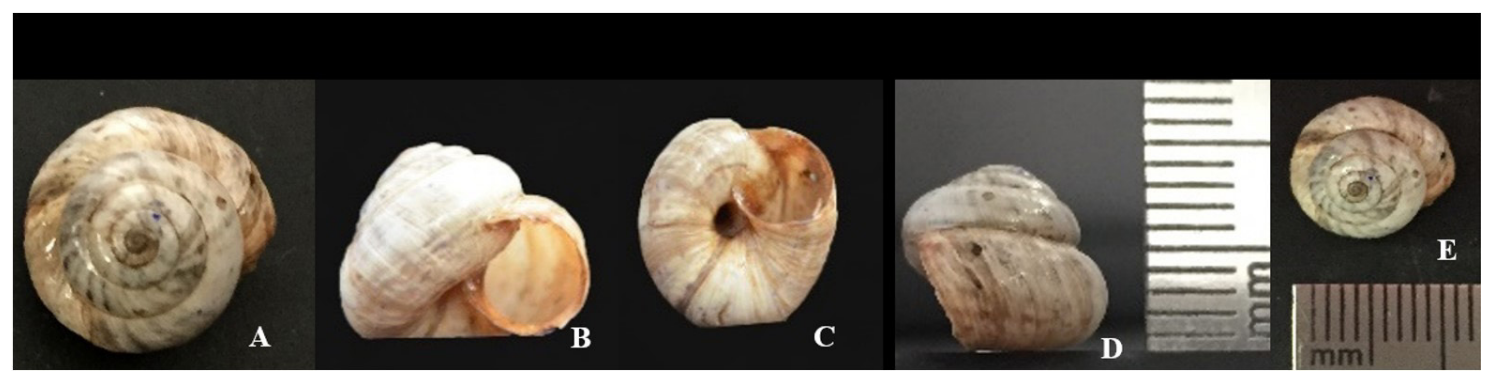

Figure 4. Family Hygromiidae Shell: (A) Periostracum, (B) Aperture, (C) Umbilicus, (D) Height of shell, (E) Width of shell.

(length) of the shell are $16.67 \mathrm{~mm}$ (Figure 3E) and $9 \mathrm{~mm}$ (Figure 3D), respectively. The shell is dextral in position i.e., right-handed coiling (Figure $3 \mathrm{~A}$ ), having a lunate aperture (Figure 3C) and narrow umbilicus (Figure 3B).

\subsection{Family Hygromiidae Tryon, 1866 (Figure 4)}

Description: Seventeen shells were identified as family Hygromiidae shells. 09 shells were collected from Deolai, 08 shells from Kokarai, making a total of 17 shells out of 417 (Table 1). Shell shape is globular and consists of 5 whorls (Figure 4A). The width and height of the shell are $12.02 \mathrm{~mm}$ (Figure 4E) and $9.75 \mathrm{~mm}$ (Figure 4D), respectively. The shell is opaque and bears multi-color small transverse lines with spotted dull background (Figure 4A). The ventral side also bears a multi-color pattern and possesses an open umbilicus (Figure 4C).

\section{Discussion}

Three families of land snails were identified: Bradybaenidae, Hygromiidae, and Zonitidae. These families were identified for the first time from Swat. The members of each of the mentioned family were collected from agricultural fields (rice or wheat fields) of Kokarai and Deolai sites while no shells of Hygromiidae was found in Kanju Township. From the collected shells, shells of Bradybaenidae were in majority (387/417 shells).

In Pakistan, Hygromiidae was reported by Rana et al. (2018) from district Faisalabad. From the same district, 15 species belonging to 7 families of Gastropods including Hygromiidae and Zonitidae were reported. The Swat region possesses a good malacofaunal diversity as reported by many malacologists (Wiktor and Auffenberg, 2002; Hlavac, 2004; Pokryszko et al., 2009). Different studies have identified gastropod families from different regions based on different aspects. For example, one family was reported by Hlavac (2004) from the Gilgit district with an approximate elevation of 1500 m.a.s.l. Members of all three families were observed in agricultural lands like rice and wheat fields (Altaf et al., 2016). A shell-less snail/slug "Candharia rutellum" belonging to the family Parmacellidae was also reported by Wiktor and Auffenberg (2002) from lower Swat. 
Different conchological characters were studied for the identification of terrestrial snail fauna. one of them is the shell height (length), which was a maximum of $9.75 \mathrm{~mm}$ in Hygromiidae approximately equal to the mean height of M. catiana species of the same family (Altaf et al., 2017a). The slight deviation in the height of the shell reported in the current study is because, we just use this feature limited to family taxon while the study of Altaf et al. (2017a) was up to species level. In Bradybaenidae the height (length) of the shell is equal to $15.37 \mathrm{~mm}$, also reported by Tan et al. (2015).

When the height (length) to width (diameter) ratios for the given family Bradybaenidae, Zonitidae and Hygromiidae were measured, it was equal to $0.59,0.53$, and 0.81 , respectively, which showed that the family Bradybaenidae and Zonitidae have sub-globose shell shape while Hygromiidae has a globose shaped shell (Altaf et al., 2017a).

Hygromiidae and Zonitidae show dark spots on white background and horny-color periostracum respectively (Altaf et al., 2017a) while Bradybaenidae has a yellow-tan color with a single stripe of chest-nut color on individual whorl (Asami et al., 1993). The family Hygromiidae has many whorls equal to 5 (Altaf et al., 2017b).

\section{Conclusion}

The current study provided further exploration of the diversity of terrestrial snail in district Swat (Khyber Pakhtunkhwa), Pakistan and aided more to the existing literature on malacofauna (especially, terrestrial snails) which is otherwise very limited. This study also provided a way for further in-depth and extensive taxonomic study on account of the described families.

\section{References}

ABBOTT, R., 1989. Compendium of Landshells: a Color Guide to More than 2,000 of the World's Terrestrial Shells. Melbourne, Florida: American Malacologists. Inc.

AHMAD, H., ÖZTÜRK, M., AHMAD, W. and KHAN, S.M., 2015. Status of natural resources in the uplands of the Swat Valley Pakistan. In: M. ÖZTÜRK, K. HAKEEM, I. FARIDAH-HANUM and R. EFE, eds. Climate change impacts on high-altitude ecosystems. USA: Springer, pp. 49-98 http://dx.doi.org/10.1007/978-3319-12859-7_2.

ALTAF, J., QURESHI, N.A. and SIDDIQUI, M.J.I., 2017b. Terrestrial snails as bioindicators of environmental degradation. Journal of Biodiversity and Environmental Sciences, vol. 10, pp. 253-264.

ALTAF, J., QURESHI, N.A. and SIDDIQUI, M.J.I., 2017a. Taxonomic studies on the occurrence of the snails (Mollusca: Gastropoda) in the agroecosystem. Journal of Biodiversity and Environmental Sciences, vol. 10, pp. 240-252.

ALTAF, J., QURESHI, N.A., RAZA, S.H. and IQBAL, M.J., 2016. Assessment of diversity and distribution of Snails (Mollusca: Gastropoda) in the Agroecosystem of Faisalabad, Pakistan. Journal of Biodiversity and Environmental Sciences, vol. 8, pp. 17-33.

ASAMI, T., FUKUDA, H. and TOMIYAMA, K., 1993. The inheritance of shell banding in the land snail Bradybaena pellucida. Venus (Japanese Journal of Malacology), vol. 52, no. 2, pp. 155-159.

CHAPMAN, A., 2009 [viewed 5 February 2021]. Numbers of living species in Australia and the world. Report for the Australian Biological Resources Study [online]. Australian Government. Available from: http://www. environment. gov. au/biodiversity/ abrs/publications/other/species-numbers/2009/pubs/nlsaw2nd-complete. Pdf

GIROD, A. and BALZARINI, A., 2017. The local forms of Zootecus (Gastropoda: Pulmonata: Subulinidae) of Pakistan: an archaeomalacological case study. Natural History Sciences : Atti della Societa Italiana di Scienze Naturali e del Museo Civico di Storia Naturale in Milano, vol. 4, no. 1, pp. 31-42. http://dx.doi. org/10.4081/nhs.2017.299.

HLAVAC, J., 2004. A new record of Deroceras laeve (O.F. Müller, 1774) from Pakistan (Gastropoda: Pulmonata: Agriolimacidae). Folia Malacologica, vol. 4, no. 4, pp. 181-182. http://dx.doi. org/10.12657/folmal.012.016.

MILLER, S. and HARLEY, J., 2001. Zoology. 5th ed. USA: The McGrawHill Companies.

POKRYSZKO, B.M., AUFFENBERG, K., HLAVÁČ, J.Č. and NAGGS, F., 2009. Pupilloidea of Pakistan (Gastropoda: pulmonata): truncatellininae, vertigininae, gastrocoptinae, pupillinae (In part). Annales Zoologici, vol. 59, no. 4, pp. 423-458. http:// dx.doi.org/10.3161/000345409X484847.

RANA, N., YASEEN, M., RUQIA, G., RASHEED, F., RIASAT, S., AFZAL, S., IMRAN, M. and IQBAL, M.Z., 2018. Distribution of soil macro fauna around dry (Rosa fields) and wet (fish farm) territory under the ecological conditions of district Faisalabad (Punjab). Pakistan Journal of Entomology and Zoology Studies, vol. 6, no. 1, pp. 48-54.

SMITH, B.J. and KERSHAW, R.C., 1979. Field guide to the non-marine molluscs of South Eastern Australia. Canberra, Australia: Australian National University Press.

TAN, S.K., LIM, K.K. and CHUA, M.A., 2015. Terrestrial snails and slugs (Mollusca: Gastropoda) of Pulau Tekong, Singapore. Nature in Singapore, vol. 8, pp. 25-30.

TOM RIDGE ENVIRONMENTAL CENTRE, 2016 [viewed 5 February 2021]. Guidelines and Procedures for the Malacology Collection of the Tom Ridge Environmental Center at Presque Isle Gastropodasnails, Bivalvia - mussels [online]. Available from: https://silo. tips/download/guidelines-and-procedures-for-the-malacologycollection-of-the-tom-ridge-environ

WIKTOR, A. and AUFFENBERG, K., 2002. Contribution to the knowledge of the terrestrial slugs of Pakistan. Folia Malacologica, vol. 10, no. 1, pp. 9-15. http://dx.doi.org/10.12657/folmal.010.002. 